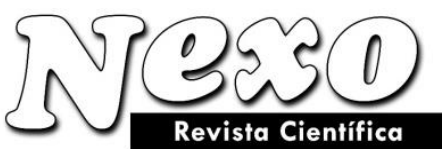

Vol. 32, No. 02, pp. 126-138/Diciembre 2019

\title{
EFFECT OF DIFFERENT PARAMETERS OF HETEROGENEOUS DAMS ON SAFETY FACTOR USING THE NEURAL NETWORK. CASE STUDY: MARVAK DAM
}

\author{
EFECTO DE DIFERNTES PARÁMETROS DE REPRESAS \\ HETEROGENEAS EN EL FACTOR DE SEGURIDAD USANDO REDES \\ NEURONALES. CASO DE ESTUDIO. REPRESA MARVAK
}

\author{
B. Beiranvand ${ }^{1, *}$, A. Mohammadzade ${ }^{1}$, M.Komasi ${ }^{2}$ \\ ${ }^{1}$ Departamento de Ingeniería Civil, Estructuras Hidráulicas y del Agua, Universidad del Ayatollah Ozma \\ Borujerdi, Borujerd, Irán \\ ${ }^{2}$ Departamento de Ingeniería Civil, Universidad del Ayatollah Ozma Borujerdi, Borujerd, Irán \\ *behrang220@gmail.com
}

(recibido/received: 01-Mayo-2019; aceptado/accepted:30-Octubre-2019)

\begin{abstract}
The drainage system is used to guide the flow of water in the earth dams. Construction of drainage in the dam body to collect and direct the drainage formed in the dam body to keep the slope dry and prevent the increase of pore water pressure in the body. One of the main goals of the designers is to find the minimum factor of safety and, consequently, reduce the cost of construction. In this study, the Marvak dam is modeled with the actual characteristics of the materials in the Geostudio software, and with the change in the dimensions of the drain, the material and the slope of the dam body, the minimum Factor of safety of the dam is obtained. In order to predict the minimum Factor of safety, a two-layer neural network has been used. With the training of the neural network based on the data obtained from heterogeneous dams, a minimum Factor of safety has been extracted for optimization of drainage. Finally, it was determined that the internal friction angle of the body material and the slope of the dam have the greatest effect on the dam factor of safety.
\end{abstract}

Keywords: Horizontal drainage; Marvak dam; Neural network; Factor of safety.

\section{RESUMEN}

El sistema de drenaje se utiliza para guiar el flujo de agua en las presas de tierra. Construcción de drenaje en el cuerpo de la presa para recoger y dirigir el drenaje formado en el cuerpo de la presa para mantener la pendiente seca y evitar el aumento de la presión de agua de los poros en el cuerpo. Uno de los principales objetivos de los diseñadores es encontrar el factor mínimo de seguridad y, en consecuencia, reducir el costo de la construcción. En este estudio, la presa Marvak se modela con las características reales de los materiales en el software Geostudio, y con el cambio en las dimensiones del drenaje, el material y la pendiente del cuerpo de la presa, el factor mínimo de seguridad de la presa es obtenido. Para predecir el Factor mínimo de seguridad, se ha utilizado una red neuronal de dos capas. Con el entrenamiento de la red neuronal basado

Nexo Revista Científica / Vol. 32, No. 02, pp. 126-138 / Diciembre 2019 
en los datos obtenidos de represas heterogéneas, se extrajo un Factor mínimo de seguridad para la optimización del drenaje. Finalmente, se determinó que el ángulo de fricción interna del material del cuerpo y la pendiente de la presa tienen el mayor efecto sobre el factor de seguridad de la presa.

Palabras claves: Drenaje horizontal; Presa Marvak; Red neuronal; Factor de seguridad.

\section{INTRODUCCIÓN}

Typically, a drainage system is used to guide the flow of water in the earth dams. The construction of a horizontal drain for collecting and guiding the water drainage formed by the dam is intended to keep the bottom slope of the downstream dam dry and prevent the increase in pore water pressure in the body of the dam. This type of drain is one of the most efficient drains, whose main task is to collect and drain water from the body of the earth dam. Also, this type of drainage, while stabilizing the earth dam body, should also have minimum dimensions. Regarding this, it seems that finding a way to calculate the position of the dimensions and the optimal shape of the horizontal drain in the earth dams is of great economic and technical importance. In order to achieve a suitable drainage plan, different design parameters such as drain length and width, number of drains and their location for these drains should be considered. If the optimal dimensions are found, the performance of these dams will be improved and, in terms of costs, the construction of the dam will be very short and cost-effective. Tesarik \& Kealy (2005) modeled a number of earth dams, providing graphs for the estimation of the horizontal drainage function in lowering the phreatic Line. Based on these graphs, the researchers analyzed two earth dams without drainage and with horizontal drainage (drainage of specified length) using a computer and laboratory model. Xu et al (2002) investigated the optimization of earth dams with two different materials by phreatic Line drop. Chahar (2004) has determined the location of the phreatic Line of the CASA Grande drawing and, in this way, has estimated the minimum and maximum horizontal drain lengths in homogeneous earth dams. Mishra and Singh (2005) studied the flow of water within the embankment, the phreatic Line position, the minimum distance between the free path and the downstream slope, and considered the position and the effective length of the horizontal drain, taking into account the water capillary effect in the soil. Alonso \& Pinyol (2008) presented the problem of water level reduction as a flow deformation problem for saturated/unsaturated conditions. In their study, the role of different soil properties in explaining the phenomena that occur at the time of discharge is discussed. Najafpour et al (1393) implemented a physical model of a homogeneous earth dam in a laboratory flume with the aim of determining and determining the optimal and anomalous angle in designing the toe drain. Then, the pore water pressure with the piezometers installed in the flume body and the volume of leakage discharge were measured volumetrically they made it. Finally, the pressure and flow rates measured in the laboratory were compared with the results of Plaxis software using SAS statistical software at $95 \%$ confidence level and 45 and 60 -degree angles and $\mathrm{P} / \mathrm{h}=0.35$ As the optimal criteria for designing the toe drain design. Malekpour et al. (2012) studied the effect of horizontal drain length and thickness on steep gradient stability under Drawdown conditions in a homogeneous earth dam. Lowe \& Karafiath in (1980), Baker et al (1993) and the American Army Corps of Engineers at (2003) are among the researchers who have studied the stability of slopes in non-drained conditions. Also, Svano \& Nordal (1987), Wright and Duncan (1987), Lane \& Griffiths (2000) and Berilgen (2007) to investigate the stability of soil gradients after surface changes Reservoir water examined the effective shear strength parameters of the soil under drainage conditions. The research emphasizes the importance of the role of drainage as one of the sustainability factors of the slopes of the earth. Some researchers, including, Duncan and Wright (2005) emphasize the role of the $\mathrm{T}$ parameter, which is called the time without the dimension of consolidation, in determining the drainage state (drainage behavior) and slope stability Earthy. According to their research, more than 99 percent of the permeate overpressure from the reservoir's reservoir drop is depreciated over 3 $\geq \mathrm{T}$, and for more time, drainage behavior should be considered in the analysis of the stability of the gradient. Zomoradiyan \& Abdollahzadeh (2012) by measuring and installing drainage upstream of dams, measured the reduction of pore water pressure and calculated the rate of improvement in factor of safety and stability. Bahrehbor et al (2017) conducted experiments on drainage systems in earth dams to select the most

Nexo Revista Científica / Vol. 32, No. 02, pp. 126-138 / Diciembre 2019 
appropriate type of drainage system to prevent leakage and internal erosion of the dam body. For this purpose, a laboratory model of a homogeneous earth dam was tested in several types of drainage in a laboratory flame with sealing in different conditions and the leakage conditions were analyzed. The results showed that the average length and thickness of the toe drainage system was $18.55 \mathrm{~m} /$ day in laboratory flume and $17.55 \mathrm{~m} /$ day in Plaxis software. The results also showed that the toe drainage system had the best slip stability with a factor of safety of 1.656 . Kalantari \& Nazeri (2016) investigated the stability of the dam with the specification of materials used in the dam. They showed the effect of different material quality on the stability of earth dams using modeling using Geostudio software. Yazdaniyan \& Afshon (2016) investigated the effect of altitude on the static standing of heterogeneous earth dams. Their models are considered for heterogeneous earth dam with same material characteristics and different heights as well as fast leakage and different permeability. For their research, they modeled two models with different heights of 62 and 133 with a crest width of 6 in Geostudio software. After comparing the results of the analysis of both models, it was found that the factor of safety for shorter dams is higher than taller dams. Fattah et al (2017) studied saturation phenomena in earth dams using Geostudio software. Their results showed that during rapid discharge of the reservoir, the pore water pressure in the dam body decreases linearly, indicating steady state flow. Darabi et al (2017) investigated the effect of drainage geometry on the dynamic response of a homogeneous dam. Their results showed that the vertical chimney drainage caused by the earthquake produced less pore water pressure than the oblique drainage. In this research, the Marvak earth dam with different characteristics of Geostudio software is modeled and by changing the dimensions of the drain, the material of the material as well as the slope of the dam, a minimum Factor of safety for the dam is obtained. Then, for different scenarios of software results using horizontal neural network, horizontal drain dimensions will be optimized. In addition, the percentage of the effect of different parameters of the dam in the factor of safety will be minimized.

\section{MATERIALS AND METHODS}

\subsection{Introduction of Marvak earth dam}

Marvak reservoir dam about $38 \mathrm{~km}$ from Dorud city in 2003 with the aim of storing 120 million $\mathrm{m}^{3} / \mathrm{year}$ of water from the river Tireh Rood, supplying 50 million $\mathrm{m}^{3}$ of water needs of Silakhor plain with the area of $5500 \mathrm{hec}$, providing the existing land rights and also Flood control is constructed. Marvak Dam is a pebble type with a clay core with a crest length of 451 meters and a crown width of 15 meters and a height of 68 meters from the riverbed (Fig. 1).

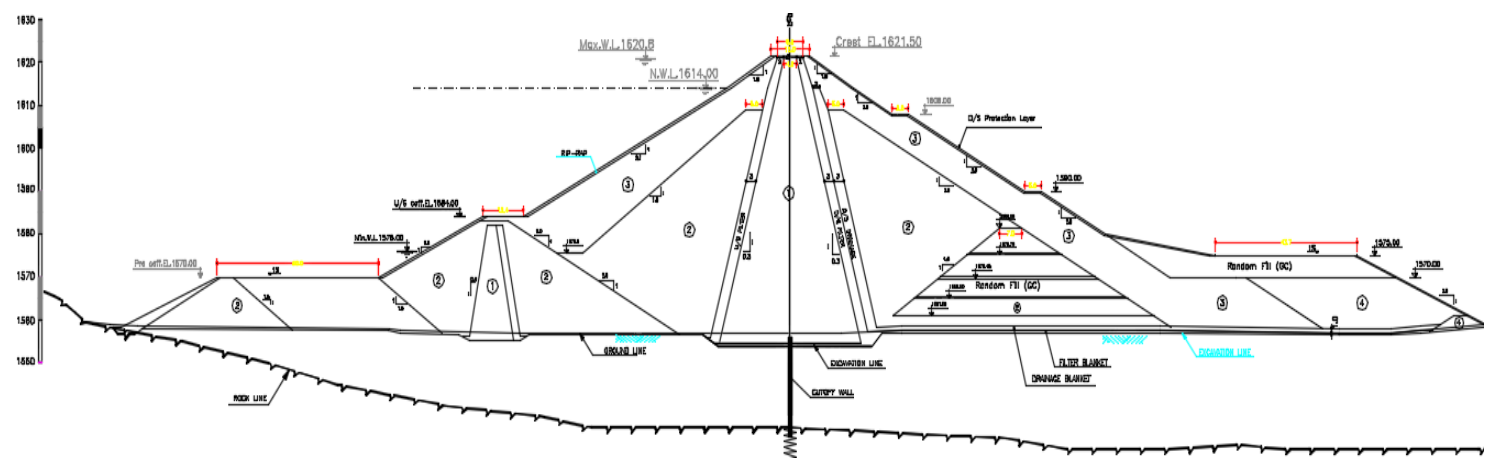

Figure 1.View of Marvak earth dam

\subsection{Modeling the Marvak earth dam with Geostudio software}

To simulate the dam, first we introduce the characteristics of the material used in the dam body to introduce the software and the geometry of the model and then define the slip and water pressure analysis using the

Nexo Revista Científica / Vol. 32, No. 02, pp. 126-138 / Diciembre 2019 
Mohr-Coulomb Behavioral Model. The parameters affecting the reliability of the Marvak earth dam are shown in Fig. 2 and the permitted range of variations of each of the parameters (Table 1).

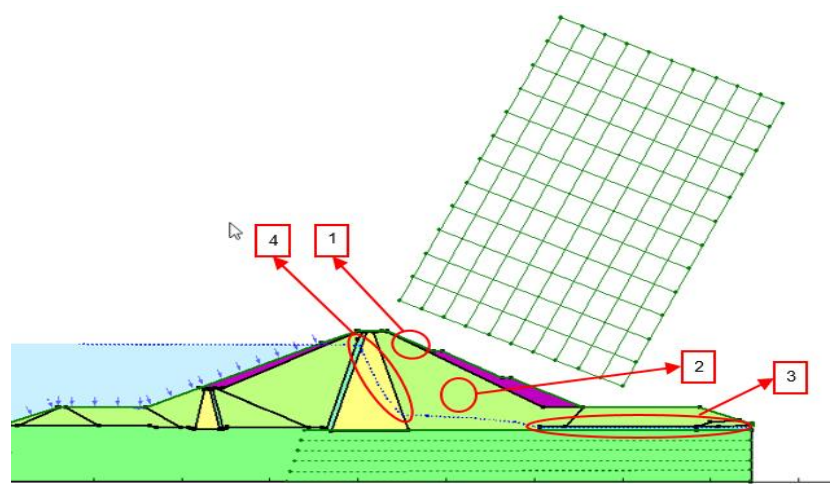

Figure 2. Morvak earth dam model in Geostudio software

Downstream slope: According to the dam construction regulations, consider the three slopes $(1: 1)$, the mean slope (1:2) and the low slope (1:3 the actual slope of the dam dam) for the downstream of the dam Taken. Internal friction angle of body material: This parameter has a value between 27 and 35 degrees. Drain length and thickness: The drainage lengths are minimum and maximum, respectively 81 and 197 meters. Determining the minimum and maximum effective length of the drain depends on other parameters of the dam. The minimum thickness of the drain is determined according to the Geostudio output. The internal friction angle of the drain material: This parameter has a value between 33 and 40 degrees. Phreatic line: The range of variations of the phreatic water line will be achieved using Geostudio results.

Table 1. Allowable range of variation of heterogeneous dam parameters

\begin{tabular}{|c|c|c|c|c|c|}
\hline $\begin{array}{c}\text { Drain } \\
\text { thickness }(\mathrm{m})\end{array}$ & $\begin{array}{c}\text { Drain } \\
\text { length }(\mathrm{m})\end{array}$ & $\begin{array}{c}\text { Dam } \\
\text { gradient }\end{array}$ & $\begin{array}{l}\text { Friction angle of } \\
\text { drainage material } \\
\quad \text { (degree) }\end{array}$ & $\begin{array}{l}\text { Internal friction angle of } \\
\text { body material (degree) }\end{array}$ & \\
\hline $2.25-3.25$ & 81-197 & $1-3$ & $33-40$ & $27-35$ & $\begin{array}{l}\text { Allowed } \\
\text { range }\end{array}$ \\
\hline
\end{tabular}

After modeling the actual parameters of the dam in the Geostudio software, the Factor of safety of 1.756 was obtained for this dam. Thus, for all predicted models, the coefficients of confidence will be obtained (Fig. 3).

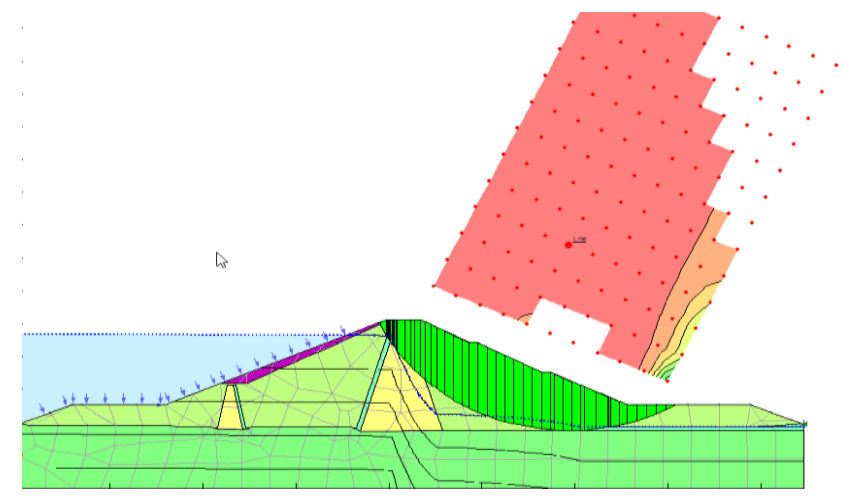

Figure 3. Marvak earth Dam Confidence

2.3. Calculation of Heterogeneous dam Factor of safety coefficient using neural network

Nexo Revista Científica / Vol. 32, No. 02, pp. 126-138 / Diciembre 2019 
Using the neural network and existing training data, one can calculate the dam factor for various parameters without the need for modeling in the Geostudio software. The desired neural network has two layers with five inputs and one output. Since the dam, height is constant, so the dam height parameter is eliminated from the neural network training process. Neural network inputs including the internal friction angle of the body body material, the internal friction angle of the drainage material, the slope of the dam, the drain thickness and the length of the drain and the output of the neural network, is the dam confinement factor. When training the neural network, only $70 \%$ of the data is used and $30 \%$ of the remaining data is used to test the network. To train the neural network from 25 neurons in the first layer and one neon in the second layer. It should be noted that the number of neurons in the first layer is based on trial and error, so that the trained neural network has the lowest number of neurons and the highest accuracy in estimating the data. In addition, the number of neurons will be able to achieve the damper's confidence in the shortest possible time. The training algorithm used for the Bayesian Regularization Neural Network, which has a longer running time and more accuracy in neural network training, than other training algorithms. Neural network training is stopped after 1000 repetitions. The R and MSE parameters of the training indicate that the value of R is very close to one and the MSE value is very close to zero, which indicates the proper training of the neural network. The Toolbox charts of the MATLAB neural network are shown in Figures 4 and 5 for dam data.

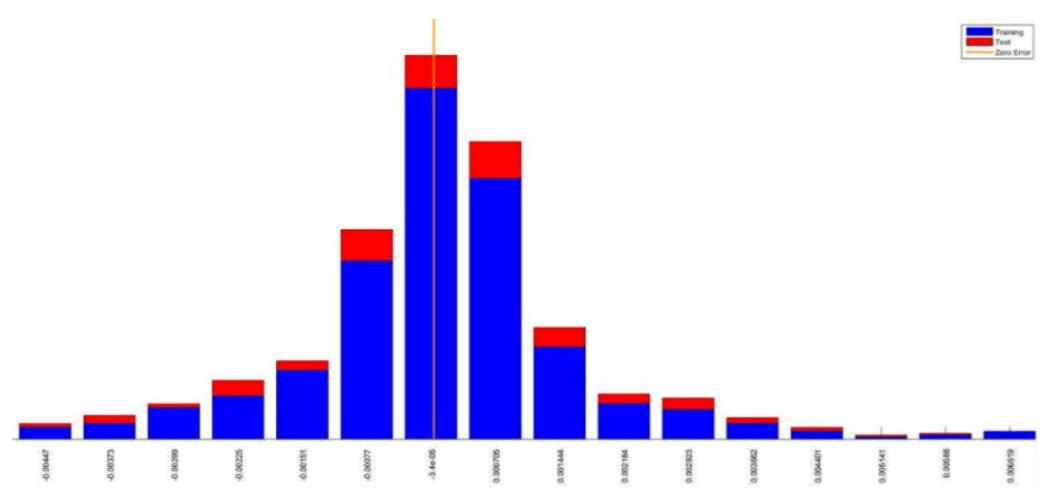

Figure 4. The error histogram of dam data
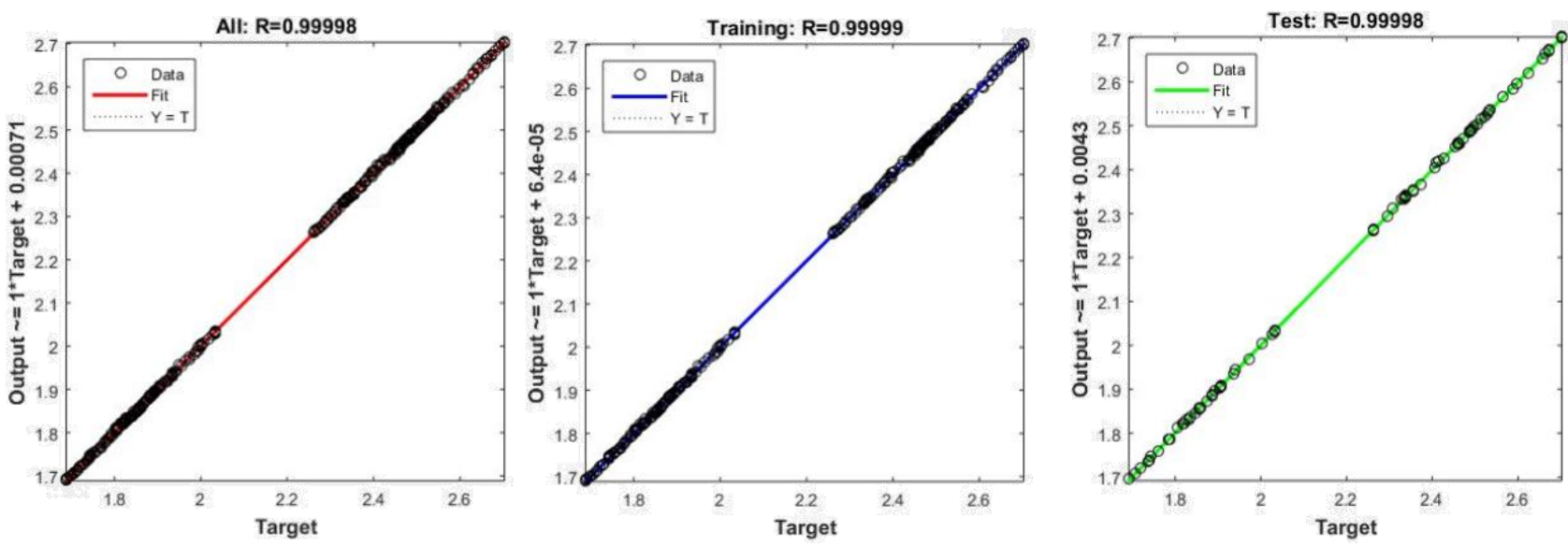

Figure 5. Dam data regression diagram

Figures 4 and 5 show the proper training of the dam's neural network. In Figure 4, which relates to the frequency of learning errors for different error values, for most data, the training error is close to zero. In addition, in Fig. 5, the data have a very high linear correlation. The results of the reliability coefficient calculated by the neural network are only -0.0025 (equivalent to -0.322 , that is, less than $1 \%$ ) of the fault in calculating the dam reliability coefficient. After training the dam's neural network, the extracted function is used to optimize the dimensions of the drain. It should be noted that the role of the neural network in the 
problem of optimizing the production of fault-proof faults. Considering that it is difficult to find a function for dam costs, therefore, in optimizing costs, the slope of the dam is optimized as the main factor in reducing costs. The optimal values of the parameters affecting the dam guarantee factor should be able to have at least the optimum damper factor (the maximum gradient, in which case the cost of building the dam is significantly reduced), the optimum drainage dimension (the product of the length in the thickness of the drain has the minimum possible value) Provide. In order to implement the optimization problem by following the priorities, an Mfile program written in MATLAB is written in which the task of producing the dam reliability factor is responsible for the neural network and calculates the optimal parameters of the dam parameters.

\section{INVESTING THE EFFECTIVE PARAMETERS IN FACTOR OF SAFETY}

To study the effective factors on the coefficient of reliability of the heterogeneous dam, Marvak dam has been used. Since height in this dam is constant, the height parameter is not considered (Table 2).

Table 2. Primary conditions for heterogeneous dam

\begin{tabular}{cccccc}
\hline $\begin{array}{c}\text { Drain length } \\
(\mathrm{m})\end{array}$ & $\begin{array}{c}\text { Drain thickness } \\
(\mathrm{m})\end{array}$ & $\begin{array}{c}\text { Dam } \\
\text { gradient }\end{array}$ & $\begin{array}{c}\text { Friction angle of drainage } \\
\text { material (degree) }\end{array}$ & $\begin{array}{c}\text { Dam angle of friction } \\
\text { (degrees) }\end{array}$ & Model \\
\hline 2.25 & 130 & $1: 3$ & 33 & 27 & $\mathrm{~A}$ \\
\hline 2.25 & 130 & $1: 3$ & 40 & 35 & $\mathrm{~B}$ \\
\hline
\end{tabular}

In this study, two modes (A) are minimal and (B) the maximum is considered for initial conditions. Considered the slope, the main slope of Marvak Dam and also the length of the drain are considered with respect to the minimum factor of safety. In addition, the drain thickness is obtained from the results of the Geostudio software. Regarding the friction angle of the body and drain, once the value of the parameters is analyzed with the least amount and again with the highest value, to determine the lowest and maximum effects of the parameters on the damping factor. The reason for considering the two modes A and B is to create the same conditions for finding the maximum effect of the friction angle of the body and the angle of friction on the drain factor. The permitted range of variation of the heterogeneous dam parameters is shown in Table 3.

Table 3. Permitted range of variation of heterogeneous dam parameters

\begin{tabular}{ccccc}
\hline $\begin{array}{c}\text { Body angle of friction } \\
\text { (degrees) }\end{array}$ & $\begin{array}{c}\text { Friction angle of drainage material } \\
(\text { degree })\end{array}$ & $\begin{array}{c}\text { Dam } \\
\text { slope }\end{array}$ & $\begin{array}{c}\text { Drain thickness } \\
(\mathrm{m})\end{array}$ & $\begin{array}{c}\text { Drain length } \\
(\mathrm{m})\end{array}$ \\
\hline 2.25 & 130 & $1: 3$ & 33 & 27,33 \\
\hline 2.25 & 130 & $1: 3$ & 33,40 & 27 \\
\hline 2.25 & 130 & $1: 3$ & 33 & 27 \\
\hline 2.25 & 81,197 & $1: 3$ & 33 & 27 \\
\hline $2.25,3.25$ & 130 & $1: 3$ & 33 & 27 \\
\hline 2.25 & 130 & $1: 3$ & 40 & 27,35 \\
\hline 2.25 & 130 & $1: 3$ & 37,40 & 35 \\
\hline 2.25 & 130 & $1: 3,1: 1$ & 40 & 35 \\
\hline 2.25 & 81,197 & $1: 3$ & 40 & 35 \\
\hline $2.25,3.25$ & 130 & $1: 3$ & 40 & 35 \\
\hline
\end{tabular}

\subsection{Model A (initial condition of the heterogeneous dam)}

Effect of the friction angle on factor of safety: In this case, the friction angle of the body is changed in steps of 27 to 30, and other parameters of the dam will have values according to Table 3 . The results of the effect of the friction angle on the dam factor of safety in A is shown in Table 4 and Fig. 5.

Nexo Revista Científica / Vol. 32, No. 02, pp. 126-138 / Diciembre 2019 
Table 4. Effect of friction angle on factor of safety (model A)

\begin{tabular}{ccccc}
\hline 30 & 29 & 28 & 27 & Body angle of friction (degree) \\
\hline 2.156 & 2.104 & 2.053 & 2.001 & factor of safety \\
\hline
\end{tabular}

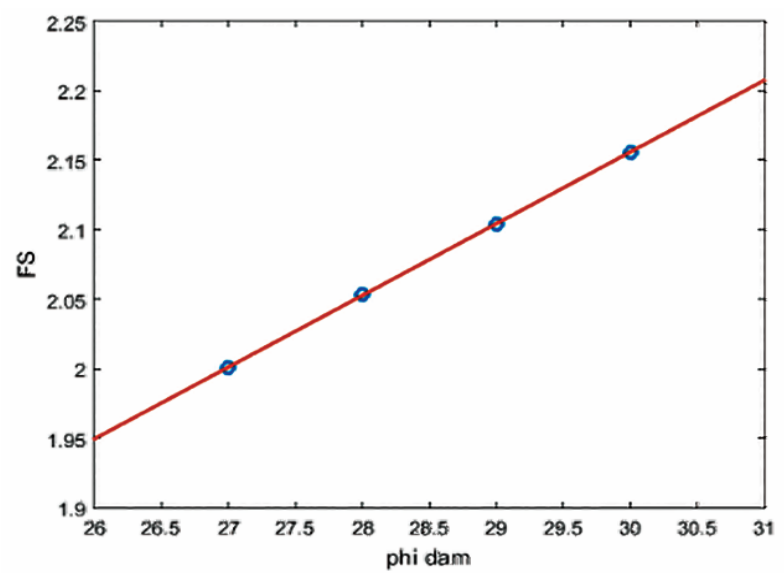

Figure 5. Linear approximation of the effect of the friction angle on factor of safety (model A)

In Model A, the maximum confidence level for the maximum friction angle change is 0.15 . With respect to Fig. 5 at first sight, it seems that a line can approximate the points. The plotted line runs exactly from all points, but to insert visual errors, enter the factor of safety in the approximated linear function and obtain the approximate angle of the friction of the body. Then it is compared with the exact amount of friction angle of the body and their difference is considered as the error of the friction angle of the body. Given that the magnitudes of this error are negligible, the linear approximation for the model A is very suitable and it can be said that the relation between the friction angle of the body and the linear factor of safety.

Effect of drainage friction angle on factor of safety: In this case, the friction angle of the drain has been changed in steps of 33 to 40 units, and other parameters of the dam will have values according to Table 3. The results of the impact of the drainage friction angle on the damping coefficient in the A state are shown in Table 5 and Fig. 6.

Table 5. Effect of drainage friction angle on factor of safety (model A)

\begin{tabular}{ccccccccc}
\hline 40 & 39 & 38 & 37 & 36 & 35 & 34 & 33 & Friction angle of drainage material (degree) \\
\hline 2.201 & 2.170 & 2.140 & 2.111 & 2.083 & 2.055 & 2.029 & 2.001 & factor of safety \\
\hline
\end{tabular}

In state $\mathrm{A}$, the maximum change in factor of safety for a maximum change in the friction angle of the drain is equal to 0.20 . We repeat the steps of the friction angle of the body for the drag angle of the drain and approximate the points in Table 5 by a line. 


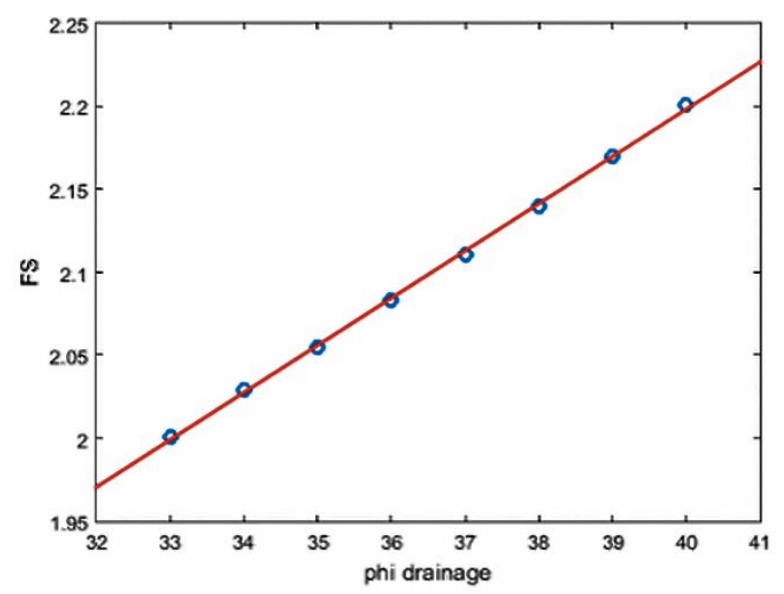

Figure 6. Linear approximation of the effect of drainage friction angle on factor of safety (model A)

As shown in Fig. 6, the drainage friction angle is linear with the dam factor of safety in A.

Effect of the slope on factor of safety: It should be noted that in this study, the gradient 1: 3 is the main slope of the Marvak dam, and the gradient 1:2 is steeper than the 1: 3 slope and 1:1 slope than the slope of 1: 2. The results of the gradient effect on the damping coefficient in the A state are shown in Table 6

Table 6. Effect of slope of the dam on factor of safety (model A)

\begin{tabular}{cccc}
\hline $1: 3$ & $1: 2$ & $1: 1$ & slope \\
\hline 2.001 & 1.881 & 1.806 & factor of safety \\
\hline
\end{tabular}

In state A, the maximum change in factor of safety for a maximum slope change of the dam is 0.195 .

Effect of drain length on factor of safety: Due to the large number of data, we change the length of the drain on larger stairs (4 meters stairs instead of 2 meters) (Table 7)

Table 7. Effect of drainage length on factor of safety (model A)

\begin{tabular}{cccccccccccc}
\hline 131 to 197 & 127 & 123 & 119 & 115 & 111 & 107 & 103 & 99 & 95 & $81-91$ & Drain length \\
\hline 2.002 & 1.995 & 1.973 & 1.941 & 1.922 & 1.895 & 1.878 & 1.859 & 1.839 & 1.820 & 1.807 & factor of safety \\
\hline
\end{tabular}

In state $\mathrm{A}$, the maximum change in the factor of safety for maximum drain length variation is 0.195 as shown in Fig. 7, the length of the drain is linear with the dam factor of safety. 


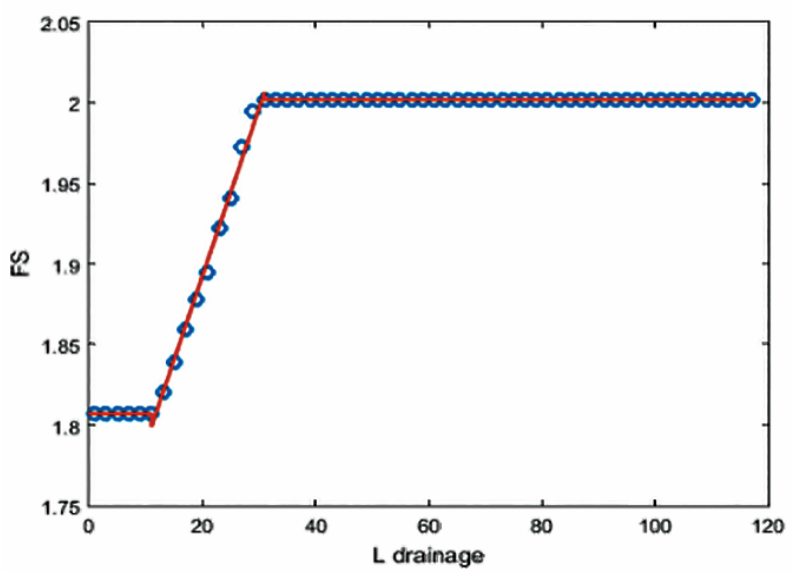

Figure 7. Linear approximation the effect of drainage length on factor of safety (model A)

Effect of drainage thickness on factor of safety: The drainage thickness in this dam has only two permitted values of 2.25 and 3.25 meters, respectively, with the corresponding factor of safetys of 2.001 and 2.019 respectively. In this case, the maximum change in factor of safety for maximum change in drain thickness is 0.018 , which is the effect of drainage thickness on the dam factor of safety because its permitted range of variations is very limited.

\subsection{Investigation of Model B (Heterogeneous Dam Conditions)}

Effect of the friction angle on factor of safety: In this case, the friction angle of the body has been changed to a single step of 27 to 35 , and other parameters of the dam will have values according to Table 3 . The results of the effect of the friction angle on factor of safety in Mode B are shown in Table 8 and Fig. 8.

Table 8. Effect of friction angle on factor of safety (model B)

\begin{tabular}{cccccccccc}
\hline 35 & 34 & 33 & 32 & 31 & 30 & 29 & 28 & 27 & Body angle of friction (degree) \\
\hline 2.640 & 2.580 & 2.522 & 2.466 & 2.410 & 2.356 & 2.303 & 2.251 & 2.201 & factor of safety \\
\hline
\end{tabular}

In this case, the maximum value of the factor of safety change for the maximum change in the friction angle of the body is 0.49 . In this case, the friction angle of the body is linear with the factor of safety (Fig. 8).

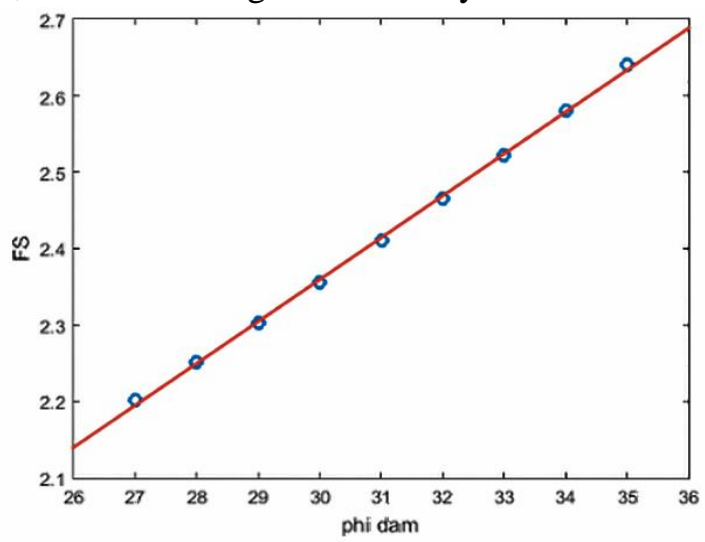

Figure 8. Linear approximation of the effect of the friction angle on factor of safety (model B)

Effect of drainage friction angle on factor of safety: In this case, the friction angle of the drain is changed in the form of single steps from 37 to 40 , and other parameters of the dam will have values according to 
Table 3. The results of the effect of the drainage friction angle on factor of safety in the state B are shown in Table 9 and Fig. 9.

Table 9. Effect of drainage friction angle on factor of safety (model B)

\begin{tabular}{ccccc}
\hline 40 & 39 & 38 & 37 & Friction angle of drainage material (degree) \\
\hline 2.640 & 2.610 & 2.580 & 2.548 & factor of safety \\
\hline
\end{tabular}

In this case, the maximum change in the factor of safety for the maximum change in the friction angle of the drain is 0.092. In this case, the friction angle of the drain is linear with the dam factor of safety (Fig. 9).

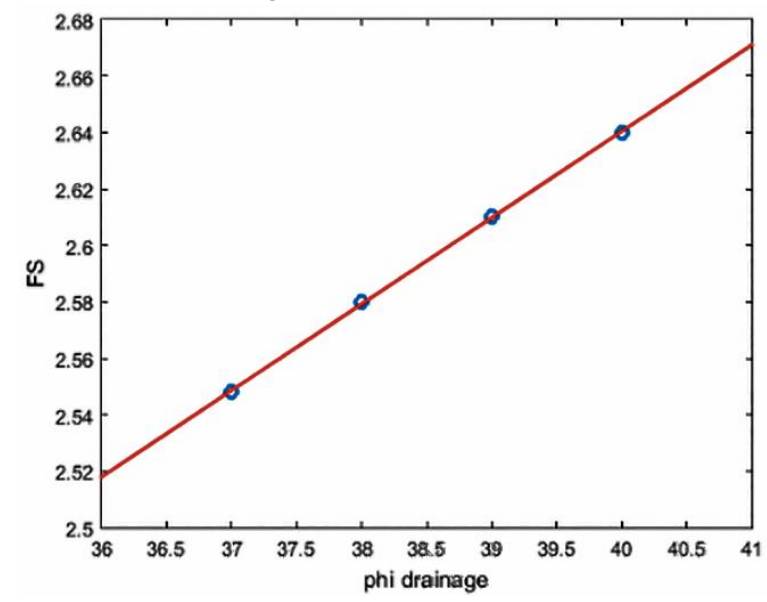

Figure 9. Linear approximation of the effect of the friction angle of the drain on factor of safety (model B)

Effect of the slope on factor of safety: Considering that this slope is 1: 3, the main slope of Marvak dam is 1: 2 slope 1: 1 slope and 1: 1 slope is steeper than 1: 1 slope. The results of the effect of the slope on the dam factor of safety in B state are shown in Table 10.

Table 10. Effect of slope of the dam on factor of safety (model B)

\begin{tabular}{cccc}
\hline $1: 3$ & $1: 2$ & $1: 1$ & slope \\
\hline 2.640 & 2.480 & 2.383 & factor of safety \\
\hline
\end{tabular}

In this case, the maximum change in the factor of safety for the maximum slope of the dam is equal to 0.257.

Effect of drain length on factor of safety: Due to the large number of data, we change the length of the drain on larger stairs (4 meters stairs instead of 2 meters) (Table 11).

Table 11. Impact of drainage length on factor of safety (model B)

\begin{tabular}{cccccccccccc}
\hline Drain length & $81-91$ & 95 & 99 & 103 & 107 & 111 & 115 & 119 & 123 & 127 & 131 to 197 \\
\hline factor of safety & 2.455 & 2.464 & 2.480 & 2.497 & 2.515 & 2.533 & 2.552 & 2.571 & 2.609 & 2.632 & 2.673
\end{tabular}

In state $\mathrm{A}$, the maximum change in the factor of safety for maximum drain length variation is 0.218 as shown in Fig. 10, the length of the drain is linear with the dam factor of safety. 


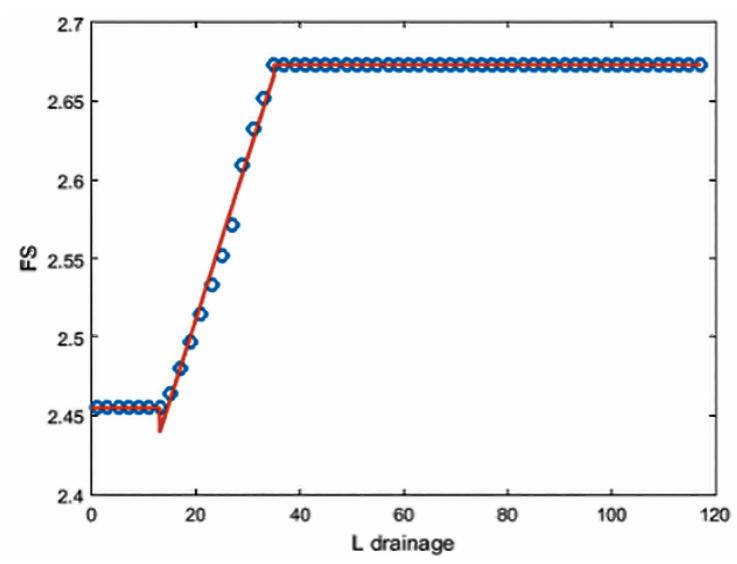

Figure 10. Linear approximation the effect of drainage length on factor of safety (model B)

Effect of drainage thickness on factor of safety: The drainage thickness in this dam has only two permitted values of 2.25 and 3.25 meters, respectively, with the corresponding factor of safetys of 2.640 and 2.657 respectively. In this case, the maximum change in factor of safety for maximum change in drain thickness is 0.018 , which is the effect of drainage thickness on the dam factor of safety because its permitted range of variations is very limited.

\section{PERCENTAGE OF THE EFFECT OF DIFFERENT PARAMETERS ON FACTOR OF SAFETY}

Maximum Effect of Parameters Effective on Marvak Dam Confidence in Equal Conditions Based on the results of the two models $\mathrm{A}$ and $\mathrm{B}$ is shown in Fig. 11.

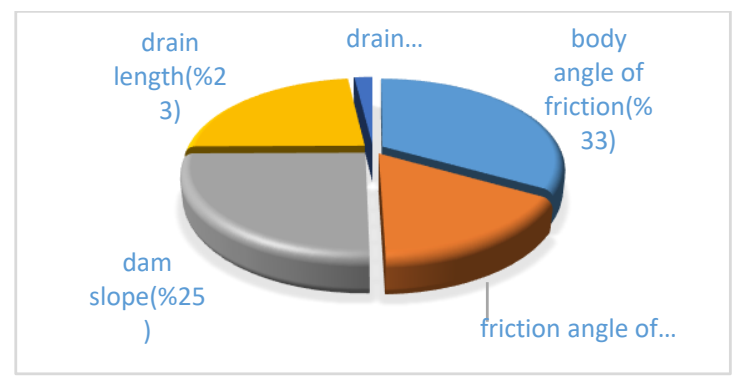

Figure 11 - Effect of Different Parameters on Marvak Dam factor of safety

The greatest influence of the parameters on the factor of safety of the dam is devoted to the friction angle of the body, the bottom slope of the dam, the length of the drain, the drainage friction angle, the thickness of the drain. From the point of view of cost reduction and minimum factor of safety, it is preferred that the dam has the highest possible gradient. In addition, materials with suitable friction angle in the dam or drainage body should be used and the length of the drain has a good value. Of course, using materials with high friction angle in the body and drainage with the maximum possible length for the drain (the maximum length effect is effective because the length of the drain does not have a significant effect on factor of safety), the minimum factor of safety the dam required is not provided. In this case, the damping gradient should reduce the optimum value of the minimum factor of safety.

\section{CONCLUSIONS}

Nexo Revista Científica / Vol. 32, No. 02, pp. 126-138 / Diciembre 2019 
In this research, the main factors affecting the factor of safety of earth dams were investigated and the maximum effect of each of the parameters on the factor of safety of the dam was determined in case and in equal conditions. Dam gradients account for a large part of the dam construction costs and have a significant impact on the dam reliability. On the other hand, the effect of the internal friction angle on the material of the dam or drainage and the length of the drain is also high on the dam reliability, with the difference that their costs are far lower. Therefore, from the point of view of cost and minimum factor of safety, it is better to optimize the slope of the dam in order to reduce the construction costs and to use the internal friction angle of the material of the dam or drainage material and the length of the drain. Finally, it was determined that the two factors of the internal friction angle of the body material and the slope of the dam have the greatest effect on the dam factor of safety.

\section{REFERENCES}

Tesarik, D.R and Kealy, C.D. (2005). Estimation horizontal drain design by the Finite-Difference method, International journal of mine water, 3:1-19

Xu, Y.Q., Unami, K., and Kawachi, T. (2002). Optimal hydraulic design of the earth dam cross-section using saturated-unsaturated seepage flow model, Elsevier, Advances in Water Resource, 26: 1-7

Chahar Bhagu, R. (2004). Determination of the length of the horizontal drain in homogeneous earth dams, Journal of irrigation and drainage engineering, 130:530-536

Mishra, G.C., and Singh, A.K. (2005). Seepage through a levee. International Journal of Geomechanics, 74: $1532-3641$

Alonso, E., and Pinyol, N. (2009). Slope stability under rapid drawdown conditions. The report, published by Universitat Politècnica de Catalunya, Barcelona.

Najafpour, N., Shayannezhad, M., and Samadi, H. (2014). Investigation of the pattern of the leakage lines and the design of paw drainage in homogeneous earth dams on impermeable soil using the PLAXIS physical and software model, Journal of Soil and Water (Agricultural Sciences and Technology). 28: 461-451.

Malekpour, A. Farsadizadeh, D. Hosseinzadeh Delir, A. and Sadr Karimi, J. (2012). The effect of the horizontal drain on the stability of homogeneous earth dam under rapid discharge conditions, Journal of Water and Soil Science. 22:139-152

Lowe, J., and Karafiath, L. (1980). Effect of anisotropic consolidation of the undrained shear strength of compacted clays, Proc Research Conference on Shear Strength of Cohesive Soils, 1-2 Feb, Boulder, Colorado. 237-258

Baker, R., Rydman, S., and Talesnick, M. (1993). Slope stability analysis for undrained loading conditions. Int J NUM and Anal Methods Geomech, 17: 14-43

US Army Corps of Engineers, (2003). Engineering and design manual slope stability, Engineer Manual EM 1110-2-1902, Department of the Army Corps of Engineers, Washington DC.

Svano, G., and Nordal, S. (1987). Undrained effective stability analysis. Proc of the 9th European Conf on Soil Mech and Found Eng, 31 Aug-3 Sep. Dublin.

Nexo Revista Científica / Vol. 32, No. 02, pp. 126-138 / Diciembre 2019 
Wright, S.G., and Duncan, J.M. (1987). An examination of slope stability computation procedures for sudden drawdown, Report GL-87-25. US Army Corps Engineers, Waterway Experiment Station.

Lane, P.A., and Griffiths, D.V. (2000). Assessment of stability of slopes under drawdown conditions. J Geotech and Geoenv Eng, 126: 443-450

Berilgen, M.M. (2007). Investigation of stability of slopes under drawdown conditions. J Computers and Geotech, 34: 81-91

Duncan, J.M., and Wright, S.G. (2005). Soil Strength and Slope Stability. John Wiley \& Sons, Inc., Hoboken, New Jersey

Zomoradiyan, M.A, Abdollahzadeh, M, (2012). The Effect of Horizontal Drainages on the Upper Slope Sustainability of Earth dams during the drawdown of the Reservoir, Journal of Civil and Environmental Engineering, 42:29-35

Bahrehbor, A. R, Bouzari. A and Bahrehbor. F. (2017). Laboratory study of the effect of the type of drainage system in the amount of leakage from the body and the homogeneous earth dam, 6th Environmental, Energy and Biological Conservation Conference, Tehran, Institute of Higher Education Arvand Stamp, Center for Sustainable Development

Kalantari, B., and Nazeri, F. (2016). Effect of material quality on the stability of embankment, EJGE Journal, 21: 5061-5071

Yazdanian, M., Afshoon, H.R., Ghasemi, S., Afshoon, V., and Fahim, F. (2017). Effect of height on the static stability of heterogeneous embankment dams, Journal of Engineering Science and Technology (ESTEC), 5:274-282

Fattah, M.Y., Omran, H.A., and Hassan, M.A. (2017). Flow and stability of Al-wand dam during the rapid drawdown of water in the reservoir, Acta Montanistica Slovaca, 22: 43-57

Darabi, M., and Maleki, M. (2017). Effect of drainage geometry on the dynamic response of homogeneous earth dams, Journal of Civil and Environmental Engineering, 48:99-108

\section{SEMBLANZA DE LOS AUTORES}

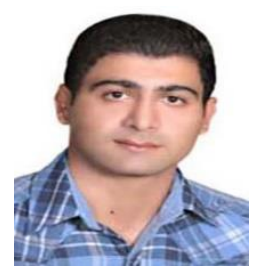

Behrang Beiranvand: Graduado del Departamento de Ingeniería de Minas en la Universidad de Ciencia e Investigación de Teherán, así como Graduado, Departamento de Ingeniería Civil, Estructuras Hidráulicas y del Agua, Universidad de Ayatollah ozma Borujerdi. Tiene 5 años de experiencia trabajando en minas y represas en Irán. También ha publicado más de 5 artículos de investigación. 